\title{
Mathematical Model Composition of Stock Price Composite Index: A Case Study of Malaysia Stock Exchange
}

\author{
Nashirah Abu Bakar ${ }^{1}$ and Sofian Rosbi ${ }^{2}$ \\ ${ }^{1}$ Islamic Business School, College of Business, University (Universiti) of Utara Malaysia, Kedah, Malaysia \\ ${ }^{2}$ School of Mechatronic Engineering, University (Universiti) of Malaysia Perlis, Malaysia
}

\begin{abstract}
The objective of this study is to analyze the composition of the Kuala Lumpur Composite Index (KLCI). In the same time, this study calculated the base index for 2019 composition. Data collected in this study using the daily stock price from Thomson Reuters Datastream. This study also analyzed the annual report for 30 companies to calculate free float of common share issued in the market. The FBM KLCI calculated using market capitalization with free float consideration. The result indicates the value of FBM KLCI on 1st January 2019 is 1683.53. This study proved that the base value for index composite calculation is 25.95 Billion. The findings of this study will help investors to have a clear overview about the calculation of index composite namely FBM KLCI. The knowledge from this study will provide an accurate perspective regarding dynamic movement behavior of index composite in Malaysia.
\end{abstract}

Key Words: Composite Index, Malaysia, Mathematical Model, Free-Float, Market Capitalization.

\section{INTRODUCTION}

Investors and fund managers are often looking for choices of investment that can lower their unsystematic risk (Saiti and Noordin, 2018). Risk can be reduce by diversify the investment through cross-border markets especially into different classes of asset such as stock, bond, real estate and Islamic investments. Forecasting volatility of shares price plays important roles in investment market. Due to unexpected return gain by investors, forecasting technique becomes crucial area that can attract most researches and practitioners to investigate (Abu Bakar and Rosbi, 2017; Fabozzi et al., 2002). According to Farid, et al., (2010) risk is defined as "without risk there is no advance" and "the higher the risk the greater the reward" are well-established truisms. Moreover, diversification of investment is one of the techniques used in monitoring the risk in investment. Investors can reduce risk even more substantially if they hold an international diversified compare if they only hold fund domestic (Bahlous and Mohd. Yusof, 2014).

Since modern portfolio theory was introduced in year 1952 (Friedman, 1971; Markowitz, 1952), many researchers have attempted to model the benefits of establishing diversification strategies for portfolio investments. Several lines of evidence suggest that modern portfolio theory considerable and contain many important studies of its suitability and application to establish an optimal allocation of property portfolios (Azizan and Sorooshian, 2014; Mohd. Ali, 2006; Friedman, 1971; Draper and Findlay, 1982). Modern portfolio theory suggested the benefits of diversification and explores how risk-averse investors construct portfolios to optimize expected returns against market risks (Bin and Yuan, 2016). There are many evidence suggested the benefit of modern portfolio theory in diversification of portfolio investment. Modern portfolio theory is a theory of finance that attempts to maximize portfolio expected return for a given amount of risk, or minimize the risk for a given level of expected return.

Study by Ou (2005) carried out a research on the modern portfolio theory and risk based on incremental entropy found the new theory emphasizes that there is an objectively optimal portfolio for given probability of returns. While, Giannotti, et al. (2011) examined the benefits of modern portfolio theory found that the standard geographic and sector diversification allow for a good results and more efficient portfolios. Study regarding the benefits of further diversifying a global portfolio of financial assets in New Zealand farm real estate found that the risk reduction benefits of diversifying with farm real estate are larger than the risk enhancement benefits (Nartea and Eves 2010).

Zainal Abidin, et al., (2004) provide evidence whether international portfolio diversification gain exists in equity investment from a Malaysian perspective and it is feasible for Malaysian investors to construct a purely domestic portfolio which is more superior to an internationally diversified portfolio under certain conditions peculiar to this market. While, Abu Bakar and Rosbi (2019) validates the performance of Kuala Lumpur Composite Index (KLCI). The significant of the findings will help investors to understand the behavior of stock price in Malaysia Stock Exchange particularly sharia-compliant companies in Kuala Lumpur 
Composite Index. Therefore, this study developed to analyze the composition of Kuala Lumpur Composite Index (KLCI) using 30 top largest companies in listed on the Malaysian stock market.

\section{LITERATURE REVIEW}

There is a vast literature on the performance of stock index worldwide. Researchers have used varies methodology to assess the performance of stock index. Abu Bakar and Rosbi (2018a) developed investment portfolio with diversifications using two different assets namely; crypto curreny (Bitcoin) and stock price (Petronas Gas Berhad) as the combination in developing investment portfolio. In this analysis, mean return for Bitcoin is $9.890 \%$ and Petron as Gas Berhad is $-0.496 \%$.The value of correlation is between two assets is -0.372 indicated that the portfolio risk can be reduced with the diversification approach for different assets.

Nguyen and Elisabeta, (2016) find the financial integration across China-ASEAN4 equity markets fluctuated between a moderate level before and after the recent crisis and a higher level during the crisis. The results indicate that investors achieve higher diversification benefits from a cross-industry than a cross-country investment strategy within this region.

Abu Bakar and Rosbi (2018b) develop efficient frontier for portfolio investment consists of two stocks form Kuala Lumpur Stock Exchange (KLSE). Daily share price is collected from Thomson Reuters DataStream. The methodology implemented in this study is statistical normality diagnostics checking, correlation analysis of two stock and mathematical modeling for Markowitz theory to achieve a global minimum of investment risk. The result shows expected portfolio return is 0.54 percentages at global minimum portfolio risk, 2.34 percentages. The findings of this study will help investors to select optimum investment weightage that minimize portfolio risk for a given amount of expected return.

\section{RESEARCH METHODOLOGY}

In validating the performance of Kuala Lumpur Composite Index (KLCI), this study evaluated calculation of composite index with implementation of statistical normality test.

\subsection{Data selection}

The FBM KLCI is a composite index using method of capitalization-weighted stock market index. The FBM KLCI composed of the 30 largest companies on the Bursa Malaysia by market capitalization that meet the eligibility requirements of the FTSE Bursa Malaysia Index Ground Rules. Table 1 shows the 30 companies that composed FBM KLCI in year 2019.

Table 1: The 30 Companies that constructed FBM KLCI in year 2019

\begin{tabular}{|c|c|c|}
\hline $\begin{array}{c}\text { COMPANY } \\
\text { ID }\end{array}$ & COMPANY NAME & SECTOR \\
\hline 1 & MALAYSIA AIRPORTS HOLDINGS BERHAD & Transportation \& logistics services \\
\hline 2 & AMMB HOLDINGS BERHAD & Banking \\
\hline 3 & AXIATA GROUP BERHAD & Telecommunications service providers \\
\hline 4 & CIMB GROUP HOLDINGS BERHAD & Banking \\
\hline 5 & DIALOG GROUP BERHAD & Energy infrastructure, equipment \& services \\
\hline 6 & DIGI.COM BERHAD & Telecommunications service providers \\
\hline 7 & GENTING MALAYSIA BERHAD & Travel, leisure \& hospitality \\
\hline 8 & GENTING BERHAD & Travel, leisure \& hospitality \\
\hline 9 & HAP SENG CONSOLIDATED BERHAD & Diversified industrials \\
\hline 10 & HARTALEGA HOLDINGS BERHAD & Health care equipment \& services \\
\hline 11 & HONG LEONG BANK BERHAD & Banking \\
\hline 12 & HONG LEONG FINANCIAL GROUP BERHAD & Banking \\
\hline 13 & IHH HEALTHCARE BERHAD & Health care providers \\
\hline 14 & IOI CORPORATION BERHAD & Food processing \\
\hline 15 & KUALA LUMPUR KEPONG BERHAD & Plantation \\
\hline 16 & MAXIS BERHAD & Telecommunications service providers \\
\hline 17 & MALAYAN BANKING BERHAD & Banking \\
\hline 18 & MISC BERHAD & Transportation \& logistics services \\
\hline 19 & NESTLE (MALAYSIA) BERHAD & Food \& beverages \\
\hline 20 & PUBLIC BANK BERHAD & Banking \\
\hline 21 & PETRONAS CHEMICALS GROUP BERHAD & Chemicals \\
\hline 22 & PETRONAS DAGANGAN BHD & Retailers \\
\hline 23 & PETRONAS GAS BERHAD & Gas, water \& multi-utilities \\
\hline
\end{tabular}


International Journal of Advances in Scientific Research and Engineering (ijasre), Vol 5 (3), March-2019

\begin{tabular}{|l|l|l|}
\hline 24 & $\begin{array}{l}\text { PRESS METAL ALUMINIUM HOLDINGS } \\
\text { BERHAD }\end{array}$ & Metals \\
\hline 25 & PPB GROUP BERHAD & Food \& beverages \\
\hline 26 & RHB BANK BERHAD & Banking \\
\hline 27 & SIME DARBY BERHAD & Industrial conglomerate \\
\hline 28 & SIME DARBY PLANTATION BERHAD & Food processing \\
\hline 29 & TENAGA NASIONAL BHD & Electric utilities \\
\hline 30 & TOP GLOVE CORPORATION BHD & Medical equipment, supplies and distribution \\
\hline
\end{tabular}

\subsection{Normality Distribution Evaluation Using Shapiro-Wilk Test}

Normal distribution data for random variable $X$ with mean $\mu$ and variance $\sigma^{2}$ is a statistic distribution with probability density function stated in Equation (1).

$$
P(x)=\frac{1}{\sigma \sqrt{2 \pi}} e^{-\frac{(x-\mu)^{2}}{2 \sigma^{2}}}
$$

In standard normal distribution, value of $\mu=0$ and $\sigma=1$ is set. Therefore, Equation (1) can be re-arrange to become Equation (2). The standard normal probability function is described as below:

$$
\varphi(x)=\frac{1}{\sqrt{2 \pi}} e^{-\frac{1}{2} x^{2}}
$$

In Equation (2), the factor $\frac{1}{\sqrt{2 \pi}}$ in this expression ensures that the total area under the curve $\varphi(x)$ is equal to one.

The factor $\frac{1}{2}$ in the exponent ensures that the distribution has unit variance. This function is symmetric around $x=0$, where it attains its maximum value $\frac{1}{\sqrt{2 \pi}}$ and has inflection points at $x=+1$ and $x=-1$. An arbitrary normal distribution can be converted to a standard normal distribution by changing variables to $Z \equiv \frac{(X-\mu)}{\sigma}$, that contributes to $d z=\frac{d x}{\sigma}$, yielding Equation (3).

$P(x) d x=\frac{1}{\sqrt{2 \pi}} e^{-\frac{z^{2}}{2}} d z$

Next, this study implemented Shapiro-Wilk test is to evaluate the data distribution according to normal distribution. Assessing the normality assumption should be taken into account for using parametric statistical tests.

The Shapiro-Wilk normality test is stated the null hypothesis is a sample $x_{1}, x_{2}, \ldots, x_{n}$ came from normally distributed population. The W-test statistics is described using Equation (4).

$$
W=\frac{\left(\sum_{i=1}^{n} a_{i} x_{(i)}\right)^{2}}{\sum_{i=1}^{n}\left(x_{i}-\bar{x}\right)^{2}}
$$

In Equation (4), the parameters are described as follow:

$x_{(i)}$ : The $i$-th order statistics. The smallest order is represented as $x_{(1)}$.

$\bar{x}$ : Sample mean calculated using $\bar{x}=\frac{\left(x_{1}, x_{2}, \ldots, x_{n}\right)}{n}$. 
$a_{i}$ are calculated using Equation (5).

$$
\left(a_{1}, a_{2}, \ldots, a_{n}\right)=\frac{m^{\mathrm{T}} V^{-1}}{C}
$$

where $C$ is a vector norm:

$$
C=\left\|V^{-1} m\right\|=\left(m^{\mathrm{T}} V^{-1} V^{-1} m\right)^{1 / 2}
$$

and vector $m$,

$m=\left(m_{1}, m_{2}, \ldots, m_{n}\right)^{\mathrm{T}}$ is made of the expected values of the order statistics of independent and identically distributed random variables sampled from the standard normal distribution;

$V$ is the covariance matrix of those normal order statistics.

\subsection{Kuala Lumpur Composite Index}

A composite index (composite) is a collection of a great many equities, other securities, or other indexes that are averaged together to represent overall market or sector performance. Typically, the elements of a composite index are combined in a standardized way in order to present large amounts of data easily. Indexes are statistical tools, which can provide a useful measure of securities' relative performance over time.

Composite indexes are created to conduct investment analysis, measure economic trends, and forecast market activity. They are used as tools for tracking securities' price changes relative to an entire stock market or sector. Therefore, they provide a useful benchmark against which to measure an investor's portfolio. The goal of a well-diversified portfolio is usually to outperform the main composite indexes.

The FTSE Bursa Malaysia KLCI Index (Kuala Lumpur Composite) is a major stock market index which tracks the performance of 30 largest companies by full market capitalization listed on the Main Board of the Bursa Malaysia. It is a free-float (minimum of 15\%), capitalization-weighted stock market index. The KLCI Index has a base value of 100 as of January 2, 1977.

The FTSE Bursa Malaysia KLCI Index comprises of the largest 30 companies by full market capitalization on Bursa Malaysia's Main Board. When launched, on July 6, 2009 it replaced the Bursa Malaysia KLCI Index starting at the closing value of the KLCI Index on July 3 2009, also inheriting the full history of the KLCI Index

\section{RESULT AND DISCUSSION}

The objective of this study is to analyze performance of FBM KLCI for Malaysia Stock Exchange. Therefore, this study implemented normality checking including mathematical derivation of composite index for FBM KLCI. This study selected 30 companies in Malaysia Stock Exchange to develop composite index. Method of calculation for composite index is free-float market capitalization weighted index.

\subsection{Data selection of FBM KLCI in Malaysia Stock Exchange}

This study collected daily FBM KLCI data from database of Thomson Reuters Data stream. Then, this study calculated average monthly value for FBM KLCI using averaging method. Observation period is selected from March 2017 until January 2019 involving 23 monthly observations. Figure 1 shows dynamic behavior of FBM KLCI in Malaysia Stock Exchange. The maximum value of FBM KLCI is 1863.15 on April 2018 (14 ${ }^{\text {th }}$ observation). Meanwhile, minimum value of FBM KLCI is 1672.91 on December $2018\left(22^{\text {nd }}\right.$ observation).

Next, this study calculated return of FBM KLCI. Figure 2 shows return rate analysis of FBM KLCI. Mean value is $-0.11 \%$ and standard deviation is $2.19 \%$. These value indicates Malaysia Stock Exchange experienced negative return with low value of volatility. 


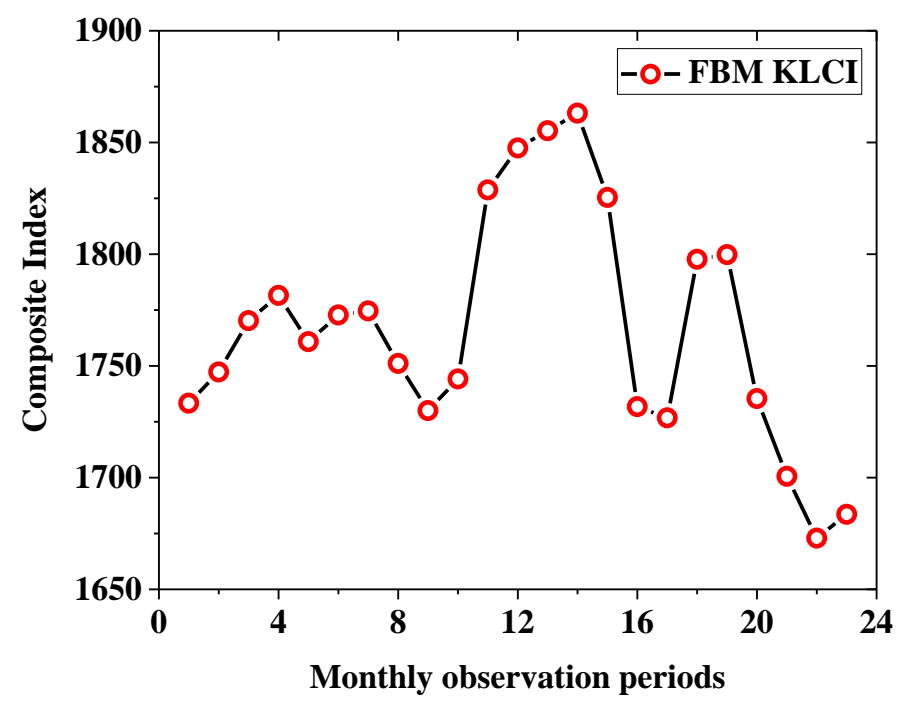

Figure 1: Dynamic behavior of FBM KLCI

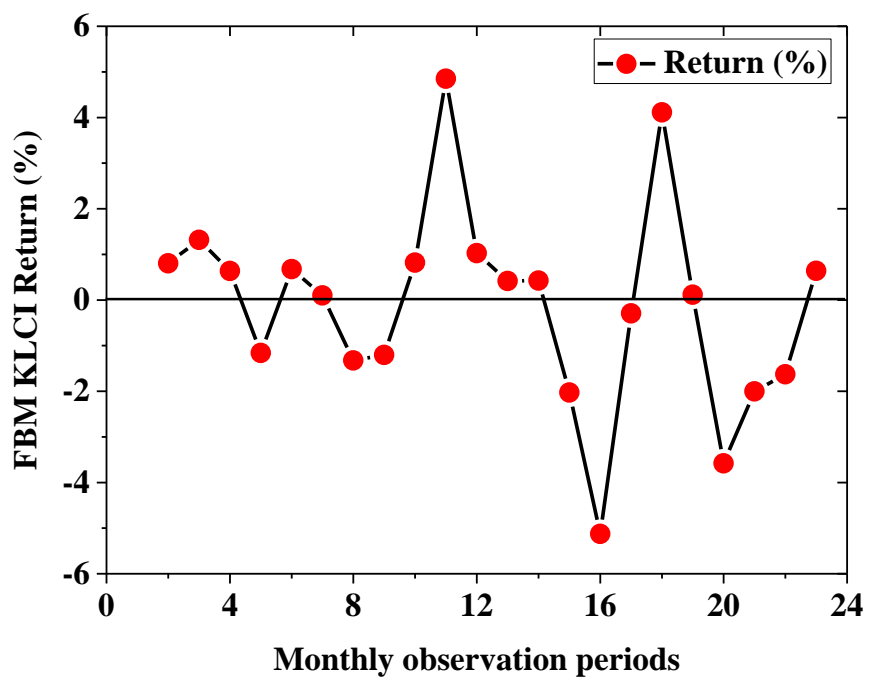

Figure 2: Return rate analysis of FBM KLCI

\subsection{Mathematical analysis of index development for free float of weighted market capitalization}

In this section, this study using calculation method of free-float of weighted market capitalization to evaluate the composite index. The free-float method is considered a better way of calculating market capitalization, because it provides a more accurate reflection of market movements and stocks actively available for trading in the market. When using a free-float methodology, the resulting market capitalization is smaller than what would result from a full market capitalization method.

The FBM KLCI is key benchmark representing Malaysian stock market. In developing this composite index, 30 stock prices are selected in developing composite index. Each company is required to have a minimum free float of $15 \%$. The free float excludes restricted shareholding like cross holdings, significant long term holdings by founders, their families or directors, restricted employee share schemes, government holdings and portfolio investments subject to a lock in clause, for the duration of that clause. A free float factor is applied to the market capitalization of each company in accordance with the banding specified in the FTSE Bursa Malaysia Ground Rules. The factor is used to determine the attribution of the company market activities in the index.

Figure 3 indicates free float percentages for 30 companies that constructed FBM KLCI. Maximum value of free float percentages is $88.37 \%$ for Malaysia Airport Holdings Berhad. Figure 4 shows free float market capitalization for 30 companies that constructed FBM KLCI. The maximum value of free float market capitalization is 60.66 Billion MYR for Public Bank Berhad. 


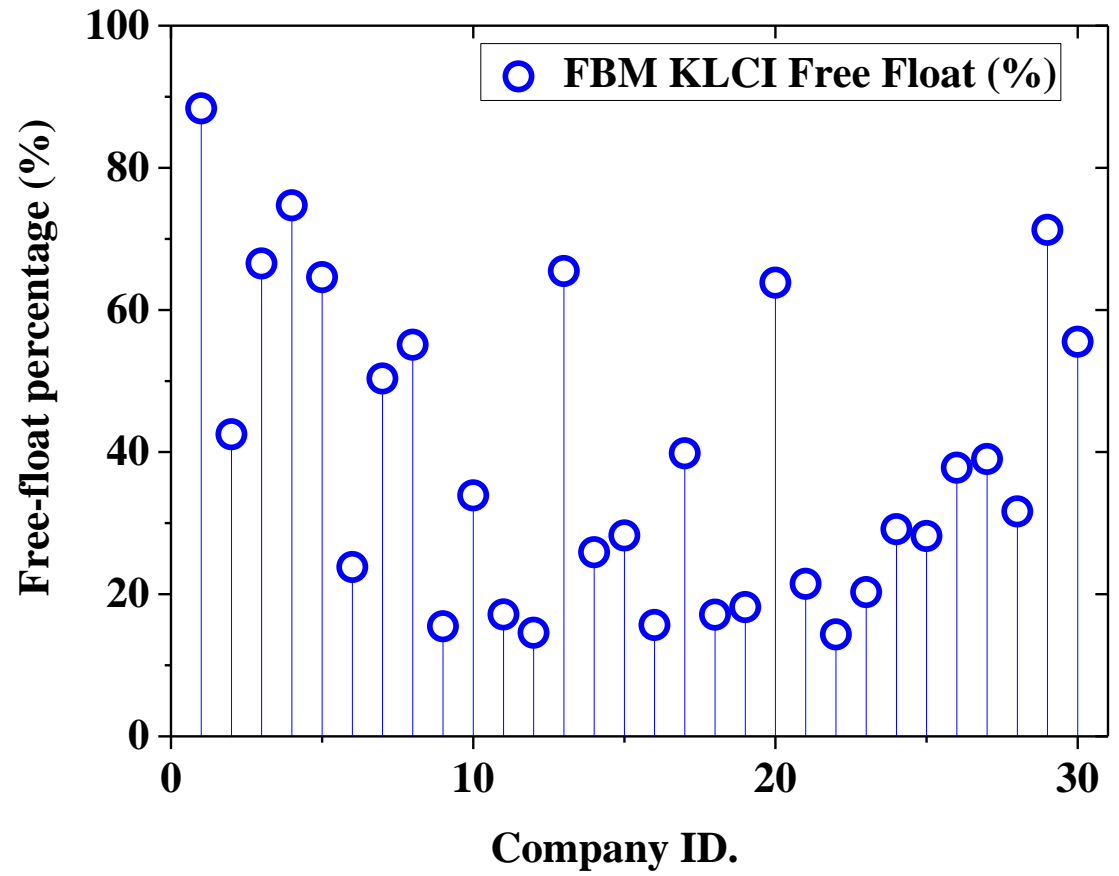

Figure 3: Free-float percentages among 30 companies

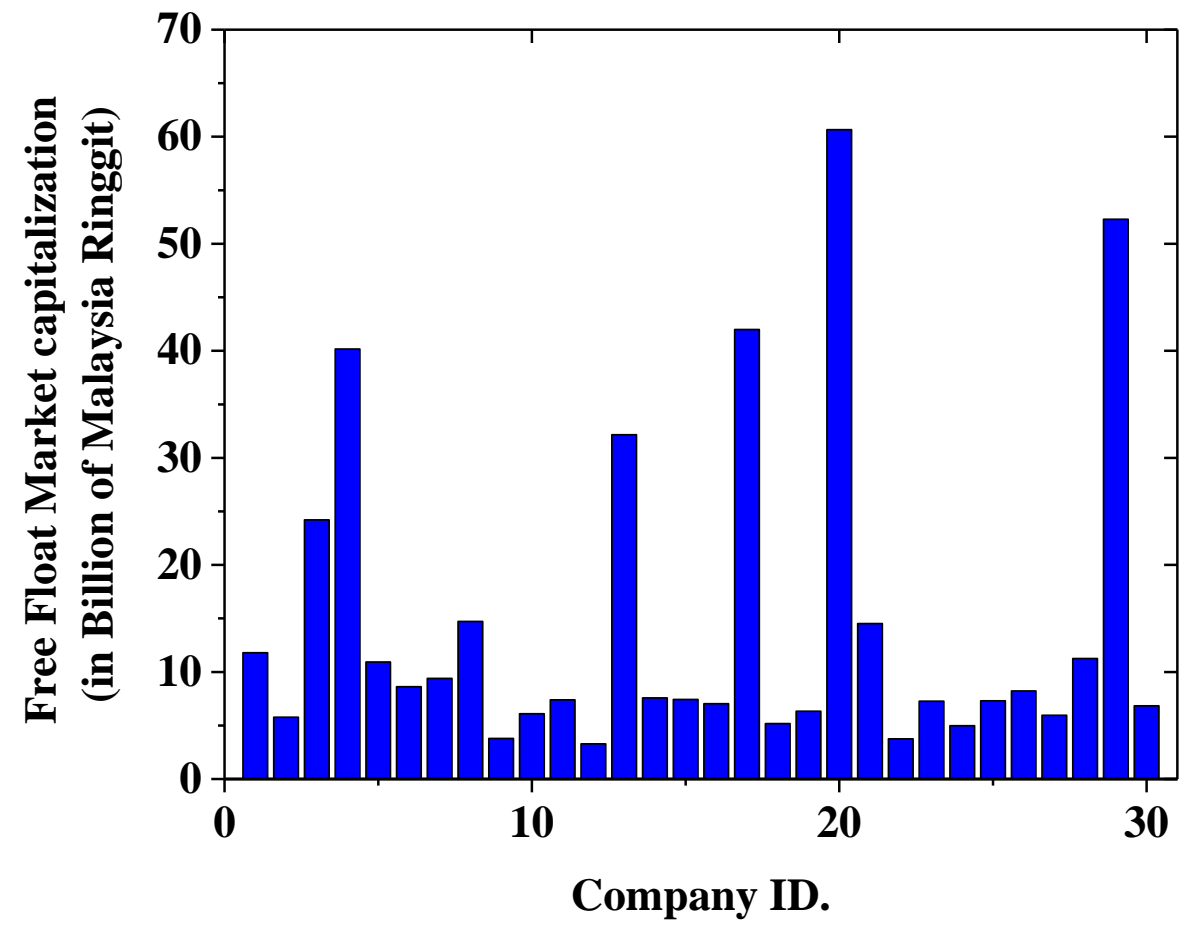

Figure 4: Free float market capitalization for 30 companies

Next, this study performed statistical analysis for data distribution of free-float market capitalization. Table 2 indicates the value of statistical test for data distribution of free-float market capitalization. This study implemented Shapiro-Wilk normality testing because sample data set is small which is 30 companies. Table 2 indicates the probability value ( $p$-value) is 0.000 that indicates this study rejected null hypothesis of normal distribution testing. Therefore, data distribution for free-float market capitalization follows non-normal distribution. In validating the finding, the skewness value is 1.935 and kurtosis value is 2.823 . Both of these values indicates the distribution of free-float market capitalization follow non-normal distribution. 
International Journal of Advances in Scientific Research and Engineering (ijasre), Vol 5 (3), March-2019

Table 2: Statistical test for data distribution of free-float market capitalization

\begin{tabular}{|c|c|c|c|c|}
\hline & Skewness & Kurtosis & $\begin{array}{c}\text { Probability value of normality } \\
\text { testing, }(p \text {-value })\end{array}$ & Data distribution \\
\hline $\begin{array}{c}\text { Free-float market } \\
\text { capitalization }\end{array}$ & 1.935 & 2.823 & 0.000 & Non-normal \\
\hline
\end{tabular}

Then, the calculation derivation of composite index FBM KLCI is composed using Equation (6).

Index $=\frac{M V_{F F}}{\text { Base }} \times 100$

In Equation (1), the parameters are described as follows:

Index : The Kuala Lumpur Composite Index (KLCI)

$M V_{F F}$ : Weighted market capitalization value with free-float consideration, and

Base : De-numerator with base coefficient for adjusting index.

In this study, as $1^{\text {st }}$ February 2019 the value of parameters in Equation (1) are described as below:

Index : The KLCI value is 1683.53 .

$M V_{F F}$ : The calculation of free float weighted market capitalization for 30 companies is 436.9 Billion.

Base : The base value is calculated to performed adjustment between market capitalization and KLCI index. Value of base coefficient is set to 25.95 Billion.

\section{CONCLUSION}

The purpose of this study is to evaluate the calculation of Kuala Lumpur Composite Index using 30 companies. The method implemented is developing FBM KLCI index is free-float weighted market capitalization. In re-structuring the KLCI, base value important to normalization of data. Therefore, main findings of this study are:

(a) This study evaluated dynamic behavior of FBM KLCI in Malaysia Stock Exchange. The maximum value of FBM KLCI is 1863.15 on April 2018. Meanwhile, minimum value of FBM KLCI is 1672.91 on December 2018.

(b) In addition, this stud also analyzed return rate of FBM KLCI. Mean value of average is $-0.11 \%$ and standard deviation is $2.19 \%$. These value indicates Malaysia Stock Exchange experienced negative return with low value of volatility.

(c) Next, this study calculated free float percentages for 30 companies that constructed FBM KLCI. Maximum value of free float percentages is $88.37 \%$ for Malaysia Airport Holdings Berhad. This study analyzed free float market capitalization for 30 companies that constructed FBM KLCI. The maximum value of free float market capitalization is 60.66 Billion MYR for Public Bank Berhad.

(d) Next, this study performed statistical analysis for data distribution of free-float market capitalization. This study implemented Shapiro-Wilk normality testing because sample data set is small which is 30 companies. The probability value ( $p$-value) is 0.000 that indicates this study rejected null hypothesis of normal distribution testing. Therefore, data distribution for free-float market capitalization follows non-normal distribution. In validating the finding, the skewness value is 1.935 and kurtosis value is 2.823 . Both of these values indicate the distribution of free-float market capitalization follow nonnormal distribution.

(e) Calculation of composite index is based on free-float weighted market capitalization. This study calculated based value of Kuala Lumpur Composite Index (KLCI) calculation in February 2019 is 25.95 Billion MYR. The value of KLCI on $1^{\text {st }}$ February 2019 is 1683.53 . 


\section{REFERENCES}

1. Abu Bakar, N. and Rosbi, S. (2017). Dynamic Forecasting Method for Shariah-compliant Share Price of Healthcare Sector in Malaysian Stock Exchange. International Journal of Advanced Engineering, Management and Science, 3(8), 855-863.

2. Abu Bakar, N. and Rosbi, S. (2018a). Diversification Diagnostics for Portfolio Investment Using Combination of Cryptocurrency and Stock Price. International Journal of Advanced Research, 6 (10), 1528-1539.

3. Abu Bakar, N. and Rosbi, S. (2018b). Efficient Frontier Analysis for Portfolio Investment in Malaysia Stock Market. Science International (Lahore), 30 (5), 723-729.

4. Abu Bakar, N. and Rosbi, S. (2019). Volatility Diagnostics for Stock Price of Sharia-Compliant Companies listed in Malaysia Composite Index. International Journal of Advanced Engineering, Management and Science, 5(2), $116-121$.

5. Azizan, N.A. and Sorooshian, S. (2014) Stock Market performance and modern portfolio theory: Case on Malaysian stock market and Asian Indices, WSEAS Transactions on Business and Economics, 11, 303313.

6. Bahlous, M. and Mohd. Yusof, R., (2014). International diversification among Islamic investments: is there any benefit. Managerial Finance, 40(6), 613-633.

7. Bin, R.L.L. and Yuan, C.J. (2016) Portfolio Diversification Strategy in the Malaysian Stock Market. Capital Markets Review, 24(1), 38-67.

8. Draper, D. W. and Findlay, M. C. (1982) Capital Asset Pricing and Real Estate Valuation. Journal of the American Real Estate and Urban Economics Association, 10, 152-183.

9. Fabozzi, F.J., Gupta, F. and Markowitz, H.M. (2002) The Legacy of Modern Portfolio Theory, The Journal of Investing, 7-22.

10. Farid, D., Meybodi, A.R. and Mirfakhraddiny, S.H. (2010). Investment risk management in Tehran Stock Exchange (TSE) using technique of Monte Carlo Simulation (MCS). Journal of Financial Crime, 17(2), 265-278.

11. Friedman, H. (1971) Real Estate Investment and Portfolio Theory, Journal of Financial and Quantitative Analysis, 6(2), 861-874.

12. Friedman, H. (1971) Real Estate Investment and Portfolio Theory. Journal of Financial and Quantitative Analysis, 6(2), 861-874.

13. Giannotti, C., Mattarocci, G. and Spinelli, L. (2011) The role of portfolio diversification in the hotel industry: Evidence from the Italian market, EuroMed Journal of Business, 6(1), 24-45.

14. Markowitz, H. (1952) Portfolio Selection, Journal of Finance, 7(1), 77-91.

15. Mohd Ali, H. (2006) Modern Portfolio Theory: Is There Any Opportunity for Real Estate Portfolio?, Malaysian Journal of Real Estate, 1(1), 14-26.

16. Nartea, G. and Eves, C., Role of farm real estate in a globally diversified asset portfolio. Journal of Property Investment \& Finance, 28(3), 198-220.

17. Nguyen, T.D. and Elisabeta, P. (2016). Financial integration and diversification benefits: China and ASEAN4 countries, Managerial Finance, 42 (5), 496-514.

18. Ou, J. (2005) Theory of portfolio and risk based on incremental entropy, The Journal of Risk Finance, 6(1), 31-39.

19. Saiti, B. and Noordin, N.H. (2018). Does Islamic equity investment provide diversification benefits to conventional investors? Evidence from the multivariate GARCH analysis. International Journal of Emerging Markets, 13(1), $267-289$.

20. Zainal Abidin, S., Ariff, M., Md. Nassir, A. and Mohamad, S. (2004) International Portfolio Diversification: A Malaysian Perspective, Investment Management and Financial Innovations, 1(3), 51-68. 